\title{
Determinants of University Choice: A Study on Economics Departments in Turkey
}

\author{
Üniversite tercihinde belirleyici faktörler: Türkiye'deki iktisat bölümleri üzerine bir çalışma \\ Murat Çokgezen \\ Department of Economics, Marmara University, Istanbul, Turkey
}

\section{Özet}

Bu çalışma, okul düzeyi verilerini kullanarak Türkiye'deki üniversite tercihini belirleyen faktörleri incelemektedir. Regresyon sonuçları, harç ücretlerinin, üniversitenin bulunduğu şehrin nüfusunun, üniversitenin akademik performansının ve öğretim dilinin, üniversite tercihini belirleyen önemli faktörlerden olduğunu göstermektedir. Sonuçlar ayrıca, devlet üniversitelerine giden öğrenciler için harç ücretlerinin, özel üniversitelere giden öğrenciler için ise akademik performansın daha önemli olduğunu göstermektedir.

Anahtar sözcükler: Harç ücreti, kalite, Türkiye, üniversite tercihi.

$\mathrm{T}$ here is much better access to higher education nowadays than in the past. Simply, there are more institutions offering more places to more people. As a result, prospective students and their families are increasingly able to choose among a range of alternatives. This availability of alternatives has led to increased competition among universities, and information about students' selection criteria has become valuable for university administrations and policy makers.

In the light of these developments, the issue of the determinants of university choice has attracted considerable attention from academics from different fields, particularly in the West. Studies examining other parts of the world, however, are limited, probably because of data limitations. The aim of this study is to make a contribution to filling this gap with an examination of school characteristics that affect students' choices of economics departments in Turkey. Although the focus of the

\begin{abstract}
This study examines determinants of university choice in Turkey using school level data. Regression results show that tuition fees, population of the city in which the university is located, academic performance of the university, and language of instruction are important determinants of university choice. The results also reveal that the impact of tuition fees is higher for public university students, while private university students care more about academic performance than do their counterparts in public universities.
\end{abstract}

Keywords: Quality, school fees, Turkey, university choice.

study is limited to economics departments in Turkey, the findings are consistent with the other studies in this field and are therefore applicable to other fields and countries.

The paper is organized as follows. The second section reviews the literature on the determinants of school choice with a specific emphasis on school characteristics. Next, there follows an overview of the university system in Turkey, which is necessary to interpret the data. The fourth section describes the model and the data used in the study. Then, empirical findings are presented and discussed before a final section concludes the study.

\section{Determinants of University Choice: Literature Review}

Students graduating from high school decide whether or not to go to university. If they choose to continue their education at a
İletişim / Correspondence:

Prof. Dr. Murat Çokgezen

Marmara University

Department of Economics

Göztepe, Istanbul, Turkey

e-mail: mcokgez@marmara.edu.tr
Yükseköğretim Dergisi 2014;4(1):23-31. @ 2014 Deomed

Geliş tarihi / Received: Eylül / September 24, 2013; Kabul tarihi / Accepted: Ocak / January 24, 2014

Cevrimiçi erissim / Online available at: www.yuksekogretim.org • doi:10.2399/yod.14.002 • Karekod / QR code:

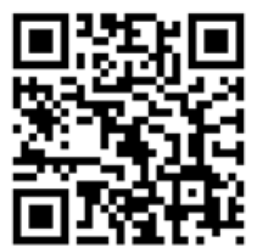


university, they then have to decide which one to attend. This study concentrates on the latter decision. ${ }^{[1]}$ Specifically, the focus is placed on prospective students' choices among alternative universities, or, more specifically, the determinants of this choice.

The determinants of a student's choice as to which university to attend have been widely examined by scholars from different disciplines. The factors affecting student choice considered in these studies can be classified into two broad categories: (a) the characteristics of the prospective student (consumer) and (b) those of the school (product). All the studies in the literature concentrate on either one or both of these aspects, depending on the aim of the researcher and data limitations.

Student characteristics are a set of variables related to students and/or those having an influence on them. For instance, 'income' or the socioeconomic status of a student and/or student's family has been identified as important determinants on school choice in many studies (Chapman, 1981; Hearn, 1984; Heller, 1997). The academic achievement of the student as measured by high school grades and/or aptitude test scores is another determinant (Chapman, 1981, Braxton, 1990). Gender (Paulsen, 1990; McDonough, 1997) and race (Hearn, 1984; McDonough, 1997) can also be added as other determinants. Studies also show that students do not decide in isolation: parents, relatives, friends, teachers, and others may all have an impact on their school selection (Chapman, 1981; Oosterbeek et al., 1992; Hossler et al. 1999).

School characteristics refers to services provided by universities that meet the expectations of students and the cost of these services. Potential students have expectations about their educational experience, like a safe and clean campus with cultural, athletic, and social activities, high quality teaching, and administrative services. They also expect both pecuniary (good salary, for instance) and/or non-pecuniary (like higher social status) returns after they graduate from a university. A student typically makes a choice from alternatives by comparing these future prospects and services provided by the university with the costs.

The influence of school characteristics is examined broadly in university choice studies. Costs are taken into account in almost all these studies as an influential factor, with school fees being the cost item mentioned most frequently. As expected, researchers have found a negative relationship between fees and demand for schools (Leslie and Brinkman, 1988; Heller, 1997; Long, 2004; McDuff, 2007). Accordingly, financial aid that reduces the costs shouldered by students has been found to be an important factor influencing school choice in the reverse direction (Leslie and Fife, 1974). However, there are also stud- ies that indicate countervailing results regarding costs. Soo and Elliot (2008) found that the fees charged do not influence the decision of the students, while Briggs and Wilson (2007) showed costs ranked only 20th in order of importance from among 22 factors.

The impact of school fees varies with other factors. Bezmen and Depken (1998) found that the demand for private universities is more price sensitive than public ones. Heller (1997) showed that low-income students are more sensitive to price changes than those are higher income students. Long, whose 2004 study examined how university choices made by students changed between 1972 and 1992, notes that the role of price declined during the time period. This study also indicates that the relative importance of price depends on the income and quality of the student, as measured by their SAT score.

In addition to fees, other cost items have also been found to be influential in the studies. Distance from home is another cost element that has a negative relationship with school choice (Soutar and Turner, 2002; Briggs and Wilson, 2007; Keskinen et al., 2008; Jepsen and Montgomery, 2009). By attending a university close to home, students may save on accommodation or transportation costs. For example, Jepsen and Montgomery's (2009) study suggests that an additional three miles (about five kilometers) from home results in a 14 percent drop in college enrollment. On the contrary, Briggs and Wilson (2007) found accommodation to have only a minor impact on school choice.

Another broad category of school characteristics is 'quality'. The perceived quality of a university is related to the services that universities offer. Since the better quality universities offer services that bring long and short term returns, they are more likely to be preferred by prospective students. Therefore, various factors that refer to the quality of a university are always included in university choice models.

Keskinen et al. (2008) stressed that teaching and department research characteristics comprise an influential factor in decision making. Soutar and Turner (2002) showed that the major determinants of university choice for school-leavers in Western Australia were course suitability, academic reputation, job prospects offered by a qualification from the university, and teaching quality. Soo and Elliot (2008) found quality of education to be positively related to number of applicants, while Isherwood (1991) found reputation of the college to be a major determinate of English-speaking students' college choice in Quebec. McDuff (2007) indicates that quality is an important determinant of school choice and that students in the US are willing to accept large tuition fee increases in exchange for a higher quality education. 
Even though the majority of studies indicate a positive relationship between quality and school choice, some studies have found opposing or conflicting results. For instance, Brigges and Wilson (2007) found no statistically significant relationship between the two for the years 1972 and 1982. Oosterbeek et al. (1992) found that earnings prospects are not a particularly important factor in the choice of a specific university, and therefore express doubt about the value for a university of increasing fees in order to improve the quality of its courses.

Finally, location is handled in university choice studies not only as a cost but also as a quality item. Students assign values to certain characteristics of the location. Research shows that students prefer socially and culturally active, big cities, like London (Soo and Elliot, 2008) and Amsterdam (Oosterbeek et al., 1992), as well as locations where they have family and friends (Keskinen et al. 2008).

School choice literature on countries outside the West is very limited. All of the studies cited above are based on the data of one or more Western countries. Only one relevant study (Yamamoto, 2006) is found for Turkey. This work, based on survey data collected from the students of a private university and concerned with the limited number of variables that influence school choice decision of students mentioned in the literature, focuses on the importance of the university entrance exam score and influence of family in university selection.

\section{The University System in Turkey}

The higher education system in Turkey is basically formed upon the 1981 Law on Higher Education. This law centralized the university system and tied all higher education institutions to the Council of Higher Education (Yiiksekögretim Kurulu, YÖK), a governmental body that regulates tertiary education in the country. Following the introduction of this legislation, all post-high school institutions (universities, academies, conservatories, vocational schools, etc.) were converted to universities or units affiliated to these universities (YÖK, 2010).

One of the major achievements of the 1981 law was a major improvement in access to higher education, achieved by increasing the supply of higher education services. The increase, which is still continuing, has had four sources. First has been the opening of new public universities. The Turkish higher education system has always been dominated by public universities. ${ }^{[2]}$ In 1982, there were just 27 public universities, a number that by 2013 had reached 109 . The second source has been the distance education system, established with the 1981 law. The distance education system in Turkey was initiated in 1982 by Anadolu University, the only university qualified for distance education until recent years. Parallel to developments in telecommunications technology, through which the education is transmitted, especially TV broadcasting, the number of students enrolled in the distance education system rocketed from 40 thousand in 1984 to 1.7 million in 2011 (Günay and Günay, 2011). ${ }^{[3]}$

The third source of increased access has been the system of secondary programs now available at many universities. With a law enacted in 1992, universities were permitted to program a second 'shift' of courses. In this secondary program, students follow the same curriculum and receive the same final qualification as the regular program students, but the starting hours of the lectures are later and tuition fees higher than those of the regular program. The final source has been the establishment of private universities. ${ }^{[4]}$ Even though the number of students enrolled at private universities comprises only a modest proportion of the total figure for all tertiary education students, it is a growing and increasingly important share. Some 25 years after the establishment of the first private university (in 1984), there are now over 60 such institutions.

Together with these developments in the expansion of higher education in Turkey, the total number of universities increased from 27 in 1982 to 179 in 2013 and the gross enrollment rate in higher education increased more than six-fold between 1980 and 2008, with the number of students enrolled to a higher institution rising from 322 thousand in 1984 to 2.1 million in 2011 (Günay and Günay, 2011). The student number increase, it should be noted, is primarily due to the explosion of distance learning at Anadolu University. According to the figures quoted, non-distance learning student numbers rose by a little more than a third between 1984 and 2011, a period in which the general population rose by about a half. Despite the developments in supply, therefore, the number of high school graduates who apply to be accepted for (on-campus) university courses remain much higher than the total number of places available. In 2010, only 55 percent of the 1.6 million university applicants were placed in a higher education program (Günay and Günay, 2011).

The limited supply in on-campus higher education in Turkey is allocated among prospective students through a centrally administrated examinations system organized by a governmental body, the Student Selection and Placement Center (Ölçme, Seçme ve Yerleştirme Merkezi, ÖSYM). For prospective

[2] In the 2005-06 educational year, 95.5 percent of higher education students in the country enrolled in public universities (YÖK, 2007, p. 27)

[3] It is claimed that the number reached over two million in 2013. See http://www.cihan.com.tr/news/Turkiye-acikogretim-ogrencisi-sayisi-bakimindan-dunyada-ikinci-siradaCHOTgzOTY5LzE=

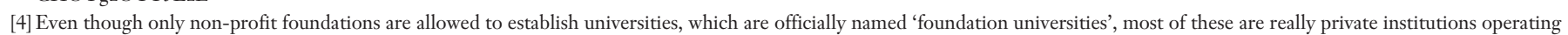
with a foundation status just to meet legal obligations (Güçlü, 2011). Therefore, the 'private' rather than 'foundation' concept is preferred here. 
undergraduates, the university entrance examination system is a two-stage process consisting of two tests, the Transition to Higher Education Examination (Yüksekögretime Geçis Sinavı, YGS) and Undergraduate Placement Examination (Lisans Yerlestirme Sinavı, LYS). Applicants qualify for the LYS by passing the initial YGS, whose scores are also used both for application to the (two-year programs at) post-secondary vocational schools and in calculating total composite scores, along with high school grade-point averages, for admission to the undergraduate programs. The aim of the central placement is to place the candidates in programs according to their list of preferences, as is compatible with their scores. The final selection and placement of students in higher education institutions is thus dependent on a combination of the composite scores of the candidates, the personal preferences they have listed, and the quotas and prerequisites of the programs. The central placement procedure admitting students according to the results of the examination system is carried out through an iterative computing routine. Each candidate can be placed in one program only.

Another major change enacted by the 1981 law related to university fees. Previously, university students had not made any financial contribution to the higher education they received. This law introduced school fees, starting from the 1984-85 academic year. Currently, tuition fees in public universities are centrally determined and set by subject, regardless of institution. Fees for the secondary program are about three times higher than those for the regular program. However, fees in public universities are low (until the 2013-14 academic year, 50 to 500 dollars per academic year, depending on the program),${ }^{[5]}$ and student contributions make up just five percent of the costs (Gürüz, 2008, p. 151). In the case of private universities, the basic sources of finance are donations ${ }^{[6]}$ and student fees. In some universities, the contribution made by students reaches 95 percent of total costs (YÖK, 2007), while the fees for some programs are as high as 12,000 dollars. ${ }^{[7]}$

The main language of instruction in Turkish universities is Turkish. However, some universities use other languages, mainly English, in all or 30 percent of their course programs. For these, students need first to attain internally (university) set scores from international English language proficiency exams (such as TOEFL or IELTS) or pass internally organized exams, for which the universities offer one-year language preparatory classes (YÖK, 2010). The caché and international access associated with English means that the highest ranked universities (and courses) tend also to be those offering English-medium instruction. This factor is also considered here.

\section{Model and Data}

The objective of this paper is to determine the impact of school characteristics on students' university choices. Based on the literature, the characteristics are grouped into two categories: cost and quality. 'Cost' refers to expenses born during the period of university education, such as school fees, accommodation, and other living costs. Students (and their families) who pay these costs expect universities to provide services in return that will meet their demands and expectations, like higher economic and social status after graduation. The courses, facilities, and suchlike offered by universities to meet these demands are referred to here as 'quality characteristics'. University selection is made after a subjective evaluation of the relevant data about these characteristics.

Cost data is usually easily accessible to decision makers. Universities announce their fees in advance. Information about living costs like rents, dormitory fees, and transportation costs can also be obtained easily enough. However, data on quality characteristics is more problematic. It is not easy for students and/or their families to evaluate whether university offers will meet their demands or not. Even if they know how to evaluate the quality, it is not easy to access the relevant data. Therefore, decision makers usually use hearsay and other ad hoc, proxy data for their evaluations. Based on these information forms and restrictions, the following model is used to determine the impact of school characteristics in university choice decisions:

$$
\begin{aligned}
\text { Score }_{i}= & \beta_{0}+\beta_{1} \text { Tuition }_{i}+\beta_{2} \text { Language }_{i}+\beta_{3} \text { Institution }_{i}+ \\
& \beta_{4} \text { Population }_{i}+\beta_{5} \text { Age }_{i}+\beta_{6} \text { Ran }_{i}+u
\end{aligned}
$$

where

Score $=$ the minimum entrance score in 2010,

Tuition $=$ annual tuition fees (in national currency),

Language $=1$ if the teaching language is other than Turkish (usually English), 0 otherwise,

Institution $=1$ if it is a state university, 0 otherwise,

Population $=$ population of the city in which the university located,

Age $=$ age of the university,

Rank $=$ rank of the university in URAP Quality Ranking based on teaching and research performance.

The data employed covers the Economics Faculty bachelor degree programs of 67 public and 24 private universities in 2011.

The data for Score is obtained from the ÖSYM 2011 Guide to General University Selection and Placement Exam. Score

[5] http://www.studyinturkey.net/life-in-turkey/fees-and-expenses. Starting from the 2013-14 academic year, minimum fees for regular programs were lifted.

[6] Contributions of the founding foundations.

[7] http://www.studyinturkey.net/life-in-turkey/fees-and-expenses 
refers to the minimum score required to enter a program. Since the supply (the number of places available on a course) is a given, higher score indicates higher demand.

Tuition, which is the major direct cost of education, is the fee charged by universities to students. As indicated, there were two tariffs in public universities in 2011: a lower fee, $313 \mathrm{TL}$ (Turkish Lira), for the regular programs, and higher fee, 1115 TL for secondary programs. Also as mentioned, the minimum entrance scores for regular programs are higher than the (equivalent) secondary programs. Private university fees are much higher than public ones, ranging between 14,500 and 31,000 TL in the sample used here. The majority of the students pay this amount, although a limited number of students benefit from scholarships, based on university entrance exam scores, and pay no fee or 25 or 50 percent of the full fee ${ }^{[8]}$ Of course, students aiming to win these scholarships need to have obtained particularly high scores than the regular students. Therefore, for some universities, depending on the availability of secondary programs and scholarship schemes, more than one Tuition and Score datum is used.
Language refers to the medium of instruction used in the university. Following the global broadening and intensification of social and economic relations among nations in recent decades, learning a foreign language, particularly English, has gained much importance. Worldwide, the increased and increasing demand for English has forced education systems and their institutions to change policies and curricula. Many schools in Turkey, including universities, have adopted English as their partial or full medium of instruction. Therefore, language is included in this model as a quality indicator affecting school choice in Turkey.

Age and Rank are introduced as two other references used to evaluate the quality of a university. Age refers simply to the age of a university, while Rank refers to the rank of a university in the (2010) Social Science Ranking of Turkish Universities created by URAP (University Ranking by Academic Performance). In collaboration with the Middle East Technical University Informatics Institute, the URAP Research Laboratory evaluates and ranks the quality of higher education institutions according to academic performance. Since there is no specific ranking for

Table 1. Descriptive statistics

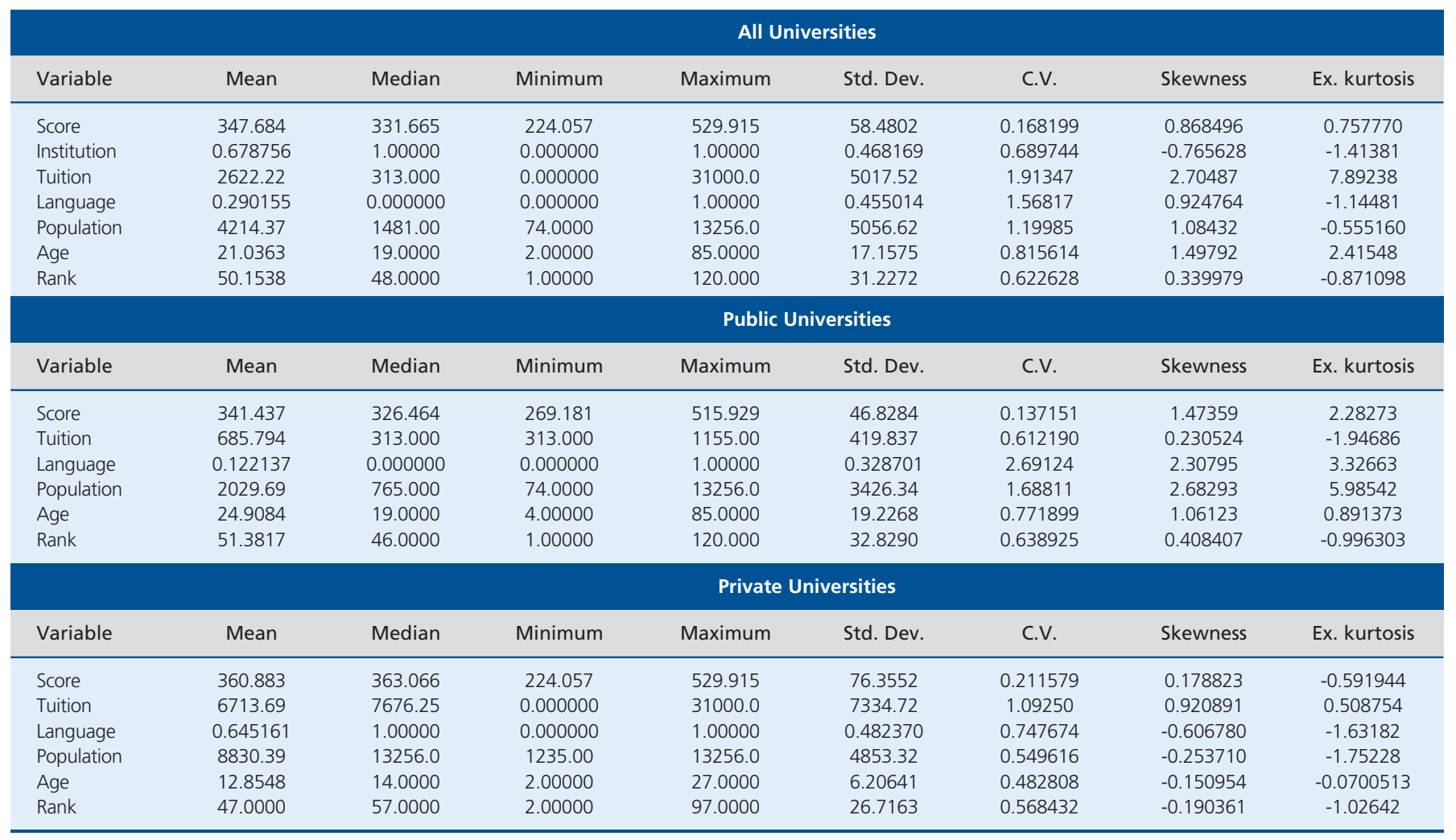

[8] Some universities even offer stipends or other material benefits to a very limited number of top students. 
economics departments, the Social Sciences ranking is used as an approximation to evaluate the academic performances of economics departments. An additional restriction of this data is the unavailability of data for three recently established private universities, due to the lack of an academic performance history. In this study, it is expected that students evaluate the age of a university and its academic ranking as quality indicators, preferring older (positive relationship with Score) and more highly ranked (negative relationship with Score, since a lower number means higher rank) universities. ${ }^{[9]}$

The source of the Population data is the Turkish Statistics Institute (Tïrkiye Istatistik Kurumu, TÜİK) population census in 2010. ${ }^{[10]}$ Population can be considered both as a cost and quality variable. On the one hand, the size of the city in which a university is situated is related to accommodation and other living costs, which is another major cost item in education. A student who prefers a university in his/her hometown and stays with his/her family can save substantially on these costs. On the other hand, big cities are attractive for university students who consider social life and the expansion of cultural horizons to be an integral part of their higher education experience. They also provide better opportunities for employment after graduation. Students tend to evaluate the university and the city as a whole, preferring big cities that offer numerous opportunities. A large proportion of prospective students grow up in large cities, of course, so these people can benefit from both the cost and quality aspects of education in this regard. Therefore, whatever the rationale, we can expect a higher demand in the cities with higher populations.

Descriptive statistics for the data are given separately for all (public and private) universities in Table 1. A comparison of public and private universities shows that mean Tuition is not only higher in private universities than in public universities, but also has higher standard errors, because of the scholarship schemes referred to. Data further show that private universities more usually offer programs in English, are much younger, located in much bigger cities and have relatively higher academic performance. Skewness is positive for all variables except

Table 2. Correlation coefficients

\begin{tabular}{|c|c|c|c|c|c|c|c|}
\hline \multirow[b]{2}{*}{ Institution } & \multirow[b]{2}{*}{ Tuition } & \multicolumn{5}{|c|}{ All Universities } & \\
\hline & & Language & Population & Age & Rank & Score & \\
\hline \multirow[t]{23}{*}{1.0000} & -0.5624 & -0.5381 & -0.6296 & 0.3289 & 0.0632 & -0.1557 & Institution \\
\hline & 1.0000 & 0.3172 & 0.3881 & -0.1508 & -0.1257 & -0.2675 & Tuition \\
\hline & & 1.0000 & 0.4024 & -0.0807 & -0.3323 & 0.3837 & Language \\
\hline & & & 1.0000 & 0.0900 & -0.2254 & 0.4175 & Population \\
\hline & & & & 1.0000 & -0.6800 & 0.3704 & Age \\
\hline & & & & & 1.0000 & -0.5542 & Rank \\
\hline & & & & & & 1.0000 & Score \\
\hline & \multicolumn{7}{|c|}{ Public Universities } \\
\hline & Tuition & Language & Population & Age & Rank & Score & \\
\hline & 1.0000 & -0.1917 & -0.1482 & -0.0655 & 0.0747 & -0.3888 & Tuition \\
\hline & & 1.0000 & 0.4512 & 0.1965 & -0.3608 & 0.5478 & Language \\
\hline & & & 1.0000 & 0.4727 & -0.5055 & 0.7396 & Population \\
\hline & & & & 1.0000 & -0.7838 & 0.6331 & Age \\
\hline & & & & & 1.0000 & -0.7063 & Rank \\
\hline & & & & & & 1.0000 & Score \\
\hline & \multicolumn{7}{|c|}{ Private Universities } \\
\hline & Tuition & Language & Population & Age & Rank & Score & \\
\hline & 1.0000 & 0.0455 & 0.0890 & 0.2282 & -0.2569 & -0.5565 & Tuition \\
\hline & & 1.0000 & -0.2659 & -0.0941 & -0.3644 & 0.1942 & Language \\
\hline & & & 1.0000 & 0.4899 & 0.3768 & 0.1199 & Population \\
\hline & & & & 1.0000 & -0.4774 & 0.2460 & Age \\
\hline & & & & & 1.0000 & -0.3528 & Rank \\
\hline & & & & & & 1.0000 & Score \\
\hline
\end{tabular}

[9] Of course, knowledge of this aspect of a university's quality characteristics may in reality be gained through word of mouth, general knowledge, etc., but the URAP listing itself is probably used since the information is easily available in Turkish and has a high Internet profile on typical Turkish as well as English language searches.

[10] Available at http://tuikapp.tuik.gov.tr/adnksdagitapp/adnks.zul 
institution. However, the signs change when data is evaluated with respect to institution type. Skewness and kurtosis values do reject the normality hypothesis for all variables at the one percent level. ${ }^{[11]}$ Since we have 182 observations, one would expect the Central Limit Theorem to apply and deviation from the normality should not be a serious concern.

Pairwise correlation coefficient estimates are given in Table 2. The signs of correlation coefficients of Score are the same in all versions and are in accordance with expectations. Correlations among independent variables are low, with the exception of the relatively high correlation between rank and age, indicating a positive relationship between age of the university and its academic reputation, as expected.

\section{Results}

Model 1 in Table 3 gives least squares estimates. BreuschPagan and White heteroscedasticity tests show that estimated models with heteroscedastic disturbances, as expected in any cross-section data. Therefore, heteroscedasticity-robust standard errors ${ }^{[12]}$ are used in estimations. Regression results show that all coefficients except Age are significant. Considering the results of Model 1 and relatively high correlation with Ranking in Model 2, the variable Age is dropped. Neither the signs nor coefficients of the variables are much changed, which holds also for goodness of fit indicators. In the new model, all coefficients are significant.

Table 3. Regression estimates

\begin{tabular}{|c|c|c|c|c|}
\hline & Coefficient & Model 1 & Model 2 & Model 3 \\
\hline Constant & $\beta_{0}$ & $\begin{array}{l}397.787^{*} \\
(15.6072)\end{array}$ & $\begin{array}{l}399.154^{\star} \\
(14.5406)\end{array}$ & $\begin{array}{l}435.985^{\star} \\
(23.6522)\end{array}$ \\
\hline Institution & $\beta 1$ & $\begin{array}{c}-21.9367^{\dagger} \\
(11.8862)\end{array}$ & $\begin{array}{c}-21.1994^{\dagger} \\
(11.0482)\end{array}$ & $-57.8885^{\ddagger}$ \\
\hline Tuition & $\beta_{2}$ & $\begin{array}{c}-0.00691 * \\
(0.000963751)\end{array}$ & $\begin{array}{c}-0.006928^{*} \\
(0.000963115)\end{array}$ & $\begin{array}{c}-0.007414^{*} \\
(0.000757783)\end{array}$ \\
\hline Language & $\beta_{3}$ & $\begin{array}{l}37.0035^{*} \\
(8.86103)\end{array}$ & $\begin{array}{l}36.7033^{*} \\
(8.90359)\end{array}$ & $\begin{array}{l}31.9170^{\ddagger} \\
(14.2666)\end{array}$ \\
\hline Population & $\beta_{4}$ & $\begin{array}{c}0.00350921^{*} \\
(0.000841032)\end{array}$ & $\begin{array}{c}0.00355696^{*} \\
(0.000793235)\end{array}$ & $\begin{array}{r}0.00399357^{\ddagger} \\
(0.00158463)\end{array}$ \\
\hline Rank & $\beta_{5}$ & $\begin{array}{c}-0.827503^{*} \\
(0.130067)\end{array}$ & $\begin{array}{l}-0.845986^{*} \\
(0.0864374)\end{array}$ & $\begin{array}{l}-1.58922^{*} \\
(0.282957)\end{array}$ \\
\hline Age & $\beta 6$ & $\begin{array}{l}0.0484994 \\
(0.216156)\end{array}$ & & \\
\hline Own tuition ${ }^{+}$ & $\beta 7$ & & & $\begin{array}{l}-0.0222013^{*} \\
(0.00435889)\end{array}$ \\
\hline Own language ${ }^{\dagger}$ & $\beta 8$ & & & $\begin{array}{l}-9.48920 \\
(18.5730)\end{array}$ \\
\hline Own population ${ }^{\dagger}$ & $\beta 9$ & & & $\begin{array}{l}0.00171521 \\
(0.00191257\end{array}$ \\
\hline Own ranking ${ }^{\dagger}$ & $\beta 10$ & & & $\begin{array}{l}0.992220^{*} \\
(0.290897)\end{array}$ \\
\hline$R^{2}$ & & 0.683989 & 0.683910 & 0.744465 \\
\hline Adjusted $R^{2}$ & & 0.673155 & 0.674930 & 0.731094 \\
\hline SE of reg. & & 33.20423 & 33.11391 & 30.11775 \\
\hline$F$ & & 66.35444 & 76.23029 & 57.67714 \\
\hline $\operatorname{Pr}(F)$ & & $1.60 e-42$ & $3.29 e-42$ & $2.35 e-47$ \\
\hline $\log L$ & & -892.1650 & -892.1878 & -872.8351 \\
\hline Akaike criterion & & 1798.330 & 1796.376 & 1765.670 \\
\hline Schwarz criterion & & 1820.758 & 1815.600 & 1797.710 \\
\hline Hannan-Quinn & & 1807.422 & 1804.169 & 1778.659 \\
\hline Breusch-Pagan & & 102.596 & 99.944866 & 104.971 \\
\hline $\operatorname{Pr}(\mathrm{BP})$ & & $7.20449 \mathrm{e}-020$ & 0.000000 & $1.54779 \mathrm{e}-018$ \\
\hline White & & 103.401 & 99.781100 & 105.368 \\
\hline $\operatorname{Pr}($ White $)$ & & $1.66728 \mathrm{e}-010$ & 0.000000 & $1.61731 \mathrm{e}-011$ \\
\hline Chow $F(5,172)$ & & & & 9.01013 \\
\hline $\operatorname{Pr}($ Chow $)$ & & & & 0.0000 \\
\hline
\end{tabular}

*1\% significance level, ${ }^{1} 0 \%$ significance level, $¥ 5 \%$ significance level

[11] The normality hypothesis is tested using Jaque-Bera (JB) statistics.

[12] All HC variants gave similar results. See Davidson and MacKinnon (2004) for a discussion about the HC variants of heteroscedasticity-robust standard errors. 
All estimates are consistent with expectations. Both models show that tuition has a negative impact on school demand. However, the coefficient of Tuition is very low. Also, students and their families care about the quality of the education provided. A single step upward movement in ranking increases minimum entrance score by 0.85 units, indicating that the academic performance of universities has an impact on school choice. Estimates also show that English as a medium of instruction is highly regarded. The minimum entrance score for economics departments using English language instruction is about 37 points higher than for the Turkish language only departments, which shows that students/families in Turkey markedly prefer these departments. Also, a low but positive relationship is found between the population of the city where the university is located and university demand, indicating the attractiveness of big cities for students and/or a preference of students to stay with their families while at university to save on accommodation and other living costs.

Even though the level of significance for Institution is lower than for the other variables, this is also found to be another determinant of school choice. As discussed above, private and public universities have certain characteristics that differ widely and which may cause differing demand structures. With this is mind, Model 2 is extended by introducing Institution in the interactive form with other variables (Model 3). A Chow test for structural difference with respect to Institution indicates that two different demand functions should be formed, one for private and one for state universities. Model 3, which is formed on this basis, shows that coefficients of Tuition and Ranking in state university demand functions are significantly different from those of private universities. Regression results indicate that the prospective students of public universities care more about costs (Tuition), while private university students are more concerned with academic performance (Ranking). Clearly, this might be explained by the income differences between the two groups of students. Since public university students typically come from lower income families than their private university counterparts, it is to be expected that this group will be more price sensitive. No significant difference is found between the two groups with regard to Language and Population.

\section{Conclusion}

The subject of the determinants of school choice has long attracted significant scholarly attraction in the West. However, evidence from other parts of the world remains limited. This study aims to contribute filling this gap by examining the determinants of school choice for economics departments in Turkey.

The wide range of determinants examined in the school choice literature can be grouped into two broad categories, stu- dent and school characteristics, of which the latter comprises the focus of this study. School characteristics basically refer to the service provided by universities and the cost of these services. Analysis of the school level data here shows that Turkish students' choices are negatively correlated with cost items and positively with service quality. Regression results indicate that students prefer universities that have a good academic reputation, are located in bigger cities, and in which the education language is in English. They also want to receive these services without paying too much.

Regression results also indicate that public university students are more price sensitive than private university students, while private university students care more about academic performance, as might be anticipated from the income differences between the two groups. All of these findings are consistent with many other studies in this field, implying that Turkish students' behavior is not much different from their counterparts in the West.

\section{References}

Bezmen, T., and Depken, C. A. (1998). School characteristics and demand for college. Economics of Education Review, 17(2), 205-210.

Braxton, J. M. (1990). How students choose colleges. In D. Hossler, J. Bean and Associates (Eds.), The strategic management of college enrollments (pp. 57-67). San Francisco: Jossey-Bass.

Briggs, S., and Wilson, A. (2007). Which university? A study of the influence of cost and information factors on Scottish undergraduate choice. Fournal of Higher Education Policy and Management, 29(1), 5772.

Chapman, D. W. (1981). A model of student college choice. Fournal of Higher Education, 52(5), 490-505.

Davidson, R., and MacKinnon, J. G. (2004). Econometric theory and methods. New York: Oxford University Press.

Güçlü, A. (2011). Türkiye'de özel üniversiteler açılsın mı? Milliyet (Turkish Daily), 14.03.2011.

Günay, D., and Günay, A. (2011). 1933'ten günümüze Türk yükseköğretiminde niceliksel gelişmeler. Yüksekögretim ve Bilim Dergisi, 1(1), 1-22.

Gürüz, K. (2008). 21. yïzyılın başında Türk Milli Eğitim sistemi. İstanbul: Türkiye İş Bankası Yayınları.

Hearn, J. (1984). The relative roles of academic ascribed and socioeconomic characteristics in college destinations. Sociology of Education, 57(1), 22-30.

Heller, D. E. (1997). Student price response in higher education: An update to Leslie and Brinkman. Fournal of Higher Education, 68(6), 624-659.

Hossler, D., Schmit, J., and Vesper, N. (1999). Going to college: Social, economic and educational factors' influence on decisions students make. Baltimore: Johns Hopkins University Press.

Isherwood, G. B. (1991). College choice: A survey of English-speaking high school students in Quebec. Canadian fournal of Education, 16(1), $72-81$.

Jepsen, C., and Montgomery M. (2009). Miles to go before learn: The effect of travel distance on the mature person's choice of a community college. Fournal of Urban Economics, 65(1), 64-73. 
Keskinen E., Juhani T., and Liimola A. (2008). University selection in Finland: how the decision is made. International Fournal of Educational Management, 22(7), 638-650.

Leslie, L., and Brinkman P. (1988). The economic value of higher education. New York, NY: American Council on Education and Macmillan.

Leslie, L. L., and Fife, J. D. (1974). The college student grant study: The enrollment and attendance impacts of student grant and scholarship programs. Fournal of Higher Education, 45(9), 651-671.

Lillard D., and Gerner J. (1999). Getting to the Ivy League: How family composition affects college choice. The fournal of Higher Education, 70(6), 706-730.

Long, B. T. (2004). How have college decisions changed over time? An application of the conditional logistic choice model. Fournal of Econometrics, 121, 271-296.

McDonough, P.M. (1997). Choosing colleges: How social class and schools structure opportunity. NewYork: SUNY Press.

McDuff, D. (2007). Quality, tuition and applications to in-state public colleges. Economics of Education Review, 26(4), 433-449.

Oosterbeek, H., Groot W., and Hartog, J. (1992). An empirical analysis of university choice and earnings. De Economist, 140(3), 293-309.
Paulsen, M. (1990). College choice: Understanding student enrollment behavior. Washington, D.C.: Eric Clearinghouse on Higher Education and George Washington University.

Soo, K. T., and Elliott, C. (2008). Price doesn't matter: Overseas students in UK higher education. Accessed through <http://wakame.econ.hitu.ac.jp/ trade/apts/2008/Papers_2008/Kwok\%20Tong\%20Soo.pdf> on February 22nd, 2012.

Soutar G. N., and Turner J. (2002). Students' preferences for university: a conjoint analysis. The international journal of Educational Management, 16(1), 40-45.

YÖK (2007). Vakıf üniversiteleri raporu [Foundation universities report]. YÖK: Ankara.

YÖK (2010). The bigher education system in Turkey. YÖK: Ankara. Accessed through <http://www.yok.gov.tr/katalog/The_higher_education_system_in_turkey.pdf> on February 22nd, 2012.

Willis, R. J., and Rosen, S. (1979). Education and self-selection. Fournal of Political Economy, 87(5), 7-36.

Yamamoto, G. T. (2006). University evaluation-selection: a Turkish case. International fournal of Educational Management, 20(7), 559-69. 